\title{
PRZEDSIĘBIORCZOŚĆ W WYBRANYCH TEORIACH EKONOMICZNYCH
}

\section{Streszczenie}

Cel - Celem artykułu jest usystematyzowanie wiedzy na temat przedsiębiorczości oraz omówienie teorii i koncepcji dotyczących przedsiębiorczości.

Metodyka badania - Artykuł ma charakter teoretyczny, dokonano w nim prezentacji przeglądu literatury krajowej i zagranicznej podejmującej tematykę przedsiębiorczości.

Wynik - W artykule dokonano prezentacji wewnętrznych i zewnętrznych czynników, które powinny charakteryzować przedsiębiorcę według koncepcji wybranych ekonomistów.

Oryginalność/wartość - W artykule podjęto próbę odpowiedzi na pytanie: czym jest przedsiębiorczość, jakie są jej rodzaje oraz jakimi cechami powinien charakteryzować się przedsiębiorca.

Słowa kluczowe: przedsiębiorca, przedsiębiorczość, rozwój przedsiębiorczości, teoria przedsiębiorczości

\section{ENTREPRENEURSHIP IN SELECTED ECONOMIC THEORIES}

\section{Summary}

Goal - The aim of the article is to systematize knowledge about entrepreneurship and presenting the theory and concept of entrepreneurship.

Research methodology - The article is theoretical. The article presents a review of national and foreign literature about entrepreneurship.

Score - The article presents the internal and external factors which should characterize the entrepreneur according to the concept of selected economists.

Originality/value - The article tries to respond to the question: What is entrepreneurship, what are its types and what characteristics should have an entrepreneur.

Keywords: entrepreneur, entrepreneurship, entrepreneurship development, entrepreneurship theory

DOI: 10.15290/wpewbmn4.2020.02 


\section{Wprowadzenie}

Najczęściej w badaniach ekonomicznych analizuje się przedsiębiorczość jako funkcję indywidualnego przedsiębiorcy. Sam termin „przedsiębiorca” wywodzi się $\mathrm{z}$ francuskiego słowa entrepreneur, którym posługiwanie się w oryginale odnotowano już na schyłku XIV wieku, choć jego rozpowszechnienie na polu naukowym miało miejsce znacznie później.

Przedsiębiorczość, pomimo iż jest bardzo często używanym pojęciem, nie posiada jednoznacznej definicji. Przedsiębiorczość można zatem charakteryzować jako ${ }^{1}$ :

- proces tworzenia czegoś nowego, np. przedsiębiorstwa zorientowanego na osiąganie korzyści na rynku,

- sposób zarządzania związany z efektywnym gospodarowaniem posiadanymi zasobami oraz odpowiednim dostosowaniem strategii do panujących warunków rynkowych,

- zespół cech charakterystycznych dla postępowania przedsiębiorcy, takich jak m.in. skłonność do podejmowania ryzyka czy elastyczność,

- innowacyjność, związaną z wdrożeniem nowatorskiego pomysłu.

Przedsiębiorczość jako specjalność naukowa posiada bogatą tradycję w historii myśli ekonomicznej, w związku z czym w pracy zastosowano krytyczną analizę i syntezę literatury przedmiotu na temat przedsiębiorczości i funkcji przedsiębiorcy. Celem artykułu jest usystematyzowanie wiedzy na temat przedsiębiorczości poprzez selektywny przegląd dostępnej literatury naukowej. W pierwszej części artykułu przedstawiono pierwsze faktyczne odniesienia do teorii przedsiębiorczości w historii ekonomii. W drugiej i trzeciej części artykułu zaprezentowano teorie przedsiębiorczości według takich ekonomistów jak Jean Baptiste Say oraz Joseph Alois Schumpeter, którzy mieli duży wkład w teorię przedsiębiorczości w ujęciu historycznym. Czwarta część artykułu została poświęcona nowszym teoriom przedsiębiorczości, ukształtowanym na schyłku XIX i w XX wieku.

\section{Teoria przedsiębiorczości Richarda Cantillona i teorie bliźniacze}

O samej zasadzie, którą powinny kierować się osoby przedsiębiorcze, czyli jak drogo sprzedać, kupując tanio, pisał już uczeń Sokratesa, grecki pisarz i historyk Ksenofont (około 430 p.n.e. - około 355 p.n.e.) ${ }^{2}$. Ksenofont w swojej pracy O gospodarstwie z 380 roku p.n.e. wskazał na istnienie dwóch sposobów na powiększenie rodzinnego majątku. Pierwszy z nich polegał na starannym zarządzaniu dostępnymi zasobami w sposób wykluczający ich utratę. Drugim sposobem było powiększanie majątku przez przedsiębiorczość kreatywną, czyli mnożąc dostępne zasoby

${ }^{1}$ J. Korol, E. Kusideł, P. Szczuciński, Przedsiębiorczość, produktywność i konkurencyjność regionów Polski, Wydawnictwo Adam Marszałek, Toruń 2016, s. 56.

2 D. Danilewicz, Wewnętrzne i zewnętrzne determinanty kształtujące postawe przedsiębiorcza, [w:] Oblicza Przedsiębiorczości, B. Glinka, J. Pasieczny, A. Postuła (red.), Warszawa 2014, s. 62. 
w ramach wymiany lub handlu. W ten sposób Ksenofont wyróżnił dwa modele efektywności powiększania majątku rodzinnego: statyczną i dynamiczną ${ }^{3}$.

Pierwsze faktyczne odniesienia do teorii przedsiębiorczości w ujęciu historycznym przypisuje się grupie fizjokratów, wywodzących się ze szkoły fizjokratycznej założonej przez francuskiego lekarza i teoretyka ekonomii François Quesnaya (1694-1774), według którego głównym źródłem bogactwa była ziemia. Quesnay i Richard Cantillon (1680-1734) stworzyli następnie wspólną wizję ekonomiczną oraz rozpoczęli badania nad teorią przedsiębiorczości, które następnie kontynuował Cantillon ${ }^{4}$.

Rysunek 1 .

Przedsiębiorcy w łańcuchu dostaw według R. Cantillona

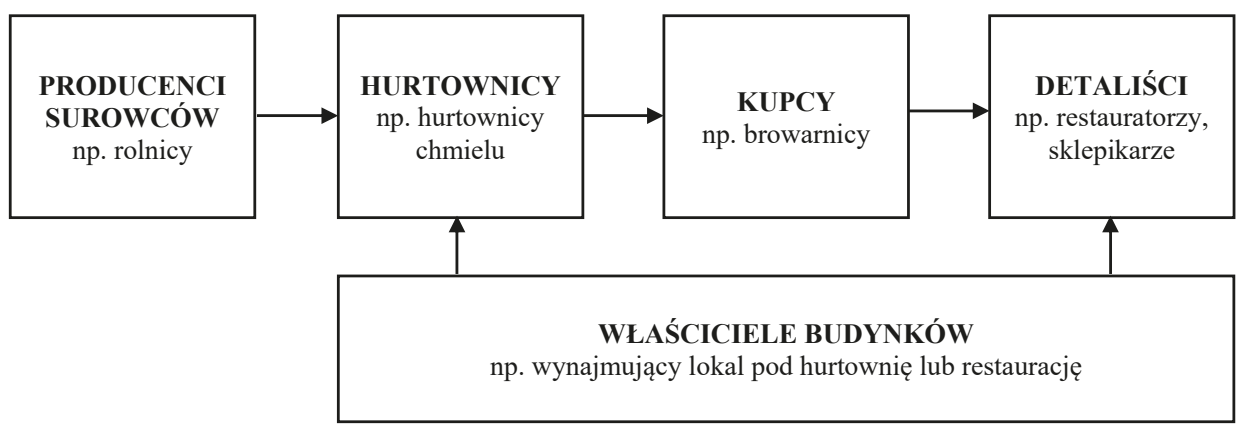

Źródło: opracowanie własne na podstawie Brown C., Thornton M., Jak teoria przedsiębiorczości stworzyła ekonomie, ,The Quarterly Journal of Austrian Economics” 2013, vol. 16, no. 4, s. 5-6.

Cantillon wskazywał na funkcjonowanie trzech głównych podmiotów w gospodarce:

- $\quad$ właścicieli jako głównych konsumentów, dążących do zaspokojenia swoich potrzeb - popytu poprzez ogół produkcji w gospodarce rozumianej jako podaż,

- przedsiębiorców, których dochód jest niepewny,

- $\quad$ pracowników najemnych, których dochód jest bezwzględny i stały ${ }^{5}$.

Teoria przedsiębiorczości Cantillona mówi o tym, że przedsiębiorcy są zmuszeni podejmować ryzyko w warunkach niepewności, ponieważ pomimo iż kupują oni produkty w cenach znanych, to w przyszłości sprzedadzą je w cenach, które nie są znane w momencie zakupu. Cantillon twierdził, że przedsiębiorczość jest nieodłącznym elementem procesu gospodarowania. Uważał, że każdy uczestnik

3 J. Huerta de Soto, Czterysta lat efektywności dynamicznej, Fundacja Instytut Ludwiga von Misesa, Wrocław 2010, s. 6.

4 H. Pelizza Vier Machado, V. Jorge Nassif, Documentos e Debates: Réplica - Empreendedores, Réplica - Empreendedores: Reflexões sobre Concepções Históricas e Contemporâneas, „RAC, Rio de Janeiro" 2014, vol. 18, no. 6, s. 892-899.

5 C. Brown, M. Thornton, Jak teoria przedsiębiorczości stworzyła ekonomię, „The Quarterly Journal of Austrian Economics" 2013, vol. 16, no. 4, s. 5. 
łańcucha dostaw, poczynając od producenta surowców, aż do detalicznego sprzedawcy produktu finalnego jest przedsiębiorcą, co zostało pokazane na podstawie produkcji i przetwórstwa chmielu (rysunek 1$)^{6}$.

Teoria przedsiębiorczości Cantillona posiada zatem szerokie zastosowanie, ponieważ zgodnie z nią każdego, kto pozyskuje i wykorzystuje zasoby w celu dalszej ich sprzedaży po nieznanej cenie, można nazwać przedsiębiorcą ${ }^{7}$ Podobną do tej teorię zaprezentował w latach późniejszych amerykański ekonomista Frank Hyneman Knight (1885-1972). Knight podkreślał, że sytuacje rynkowe, z którymi spotykają się przedsiębiorcy, nie pozwalają do końca określić efektywności podejmowanych przez nich inwestycji. Przedsiębiorcy mogą zatem jedynie oszacować zwrot z inwestycji, a oszacowania w dużej mierze zależą od pewności siebie i poczucia wartości osoby dokonującej oszacowań. Knight stwierdził, że przedsiębiorcy charakteryzują się dużą pewnością siebie, co wyróżnia ich na tle innych ludzi ${ }^{8}$. Kolejną bliźniaczą teorię do teorii Cantillona prezentował Ludwig Heinrich Edler von Mises (1881-1973), który porównał zachodzące procesy rynkowe do pewnego rodzaju gry, gdzie przedsiębiorca, działając w warunkach niepewności, zmuszony do spekulacji, chce osiągać jak najwyższe korzyści ze sprzedaży (maksymalizacja zysku), a konsument chce kupić produkt po jak najniższej cenie (minimalizacja kosztów). Zatem jedynym źródłem, z którego przedsiębiorca czerpie zyski jest to, że potrafi lepiej niż konkurenci przewidzieć przyszłe potrzeby konsumentów. Jeżeli przedsiębiorca niewłaściwie zaprognozuje przyszłość rynkową, czeka go porażka ${ }^{9}$.

\section{Przedsiębiorczość i przedsiębiorca według Jean Baptiste Saya}

Kolejne wzmianki na temat przedsiębiorczości oraz podkreślenie znaczenia przedsiębiorcy pojawiły się w rozważaniach francuskiego przedstawiciela nurtu ekonomii klasycznej, a zarazem przedsiębiorcy i ekonomisty Jean Baptiste Saya (1767-1832). Say dokonał trójpodziału funkcji, które można dostrzec w każdym procesie produkcji, a mianowicie podzielił ją na wysiłek, wiedzę oraz dystrybucję produktu. Uznał, że oczywistym jest, iż bez podstawowej wiedzy, nie istnieje możliwość wytworzenia produktu, ale bez poniesionego wysiłku sama wiedza nie wystarczy do osiągnięcia produktu finalnego. Do tego celu był potrzebny przedsiębiorca, który stał się najważniejszym organem procesu produkcji. Przedsiębiorca nie był w stanie zorganizować sam całego procesu produkcji bez pozostałych operacji, ale miał mieć na nie wpływ i przypisywać im konkretne wartości.

Jean Baptiste Say uchodzi za ekonomistę, który jako pierwszy wprowadził pojęcie przedsiębiorcy do teorii ekonomii. Jednak we wszystkich przedstawionych

\footnotetext{
Ibidem, s. 5-6.

Ibidem.

A. Macko, T. Tyszka, Przedsiębiorczość i ryzykowanie, „Decyzje” 2005, nr 4, s. 39-40.

9 L. von Mises, Ludzkie działanie, Traktat o ekonomii, Instytut Ludwiga von Misesa, Warszawa 2007, s. 251.
} 
dotychczas teoriach przedsiębiorca jest tylko organizatorem procesu produkcji, najczęściej jest także właścicielem kapitału i pracodawcą ${ }^{10}$.

\section{Schumpeterowska teoria przedsiębiorcy i jej rozwój}

Austriacki ekonomista Joseph Alois Schumpeter (1883-1950) miał odmienną wizję przedsiębiorczości. Według niego przedsiębiorczość polega na tworzeniu i rozpowszechnianiu nowych produktów, wprowadzaniu nowych metod wytwarzania, znajdywaniu nowych rynków zbytu, budowaniu nowych form gospodarczych oraz odkrywaniu nowych źródeł zaopatrzenia w surowce i materiały ${ }^{11}$. Przedsiębiorcą natomiast jest osoba spełniająca wymogi przedsiębiorczości. Schumpeter postrzega przedsiębiorcę jako człowieka rozwijającego się, ciągle poszukującego nowości w swojej branży i skłonnego do wprowadzania innowacji, który nie musi posiadać własnych zasobów kapitału.

Ponadto, Schumpeter uznał, że przedsiębiorca, który nie realizuje już nowych kombinacji, zaczął prowadzić swoje przedsiębiorstwo w sposób „codzienny”, nie wprowadzając wielu zmian w jego funkcjonowaniu stracił status przedsiębiorcy i stał się biznesmenem. Schumpeter dostrzega jeszcze inne, silniejsze niż maksymalizacja zysku, bodźce motywujące przedsiębiorcę do działania. Autor ten znacznie odbiega w swoich rozważaniach o przedsiębiorcy od koncepcji homo oeconomicus, która identyfikuje istotę działania jednostki w ujęciu głównego nurtu ekonomii. Schumpeter pokazuje, że przedsiębiorca nie jest osobą dążącą jedynie do maksymalizacji zysku, a większość jego działań wynika z pobudek indywidualnych (rysunek 2$)^{12}$.

Teorię Schumpetera rozwinął następnie francuski doktor i ekspert ds. zarządzania Peter Drucker (1909-2005), podkreślając rolę przedsiębiorcy jako innowatora. Drucker uznawał przedsiębiorczość za cechę postawy człowieka, która oznacza gotowość do samodzielnego rozwiązywania nowych, dotąd niepojawiających się problemów przy wykorzystaniu innowacyjnych, kreatywnych rozwiązań, z jednoczesną świadomością ryzyka oraz umiejętnością wykorzystywania szans, a także elastycznością w dopasowywaniu się do ciągle zmieniających się warunków ${ }^{13}$.

\footnotetext{
${ }^{10}$ G. Koolman, Say's Conception of the Role of the Entrepreneur, „Economica New Series”, vol. 38, no. 151, s. 269-286.

${ }^{11}$ J.C. Huefner, H.K. Hunt, P.B. Robinson, D.V. Stimpson, An Attitude Approach to the Prediction of Entrepreneurship, „Entrepreneurship: Theory \& Practice” 1991, s. 14-15.

${ }^{12}$ A. Glapiński, Schumpeterowska teoria przedsiębiorcy, czyli skąd się bierze pies, „Konsumpcja i rozwój” 2012, nr 1(2), s. 7-10.

${ }^{13} \mathrm{M}$. Belniak, Internacjonalizacja jako kierunek rozwoju przedsiębiorczości firm w województwie małopolskim - wyniki badań empirycznych, [w:] J. Majczyk, M. Darecki, A. Postuła (red.) Przedsiębiorczość: jednostka, organizacja, kontekst, Wydawnictwo Naukowe Wydziału Zarządzania Uniwersytetu Warszawskiego, Warszawa 2015, s. 63.
} 
Rysunek 2 .

Źródła motywujące przedsiębiorcę do działania według Josepha A. Schumpetera

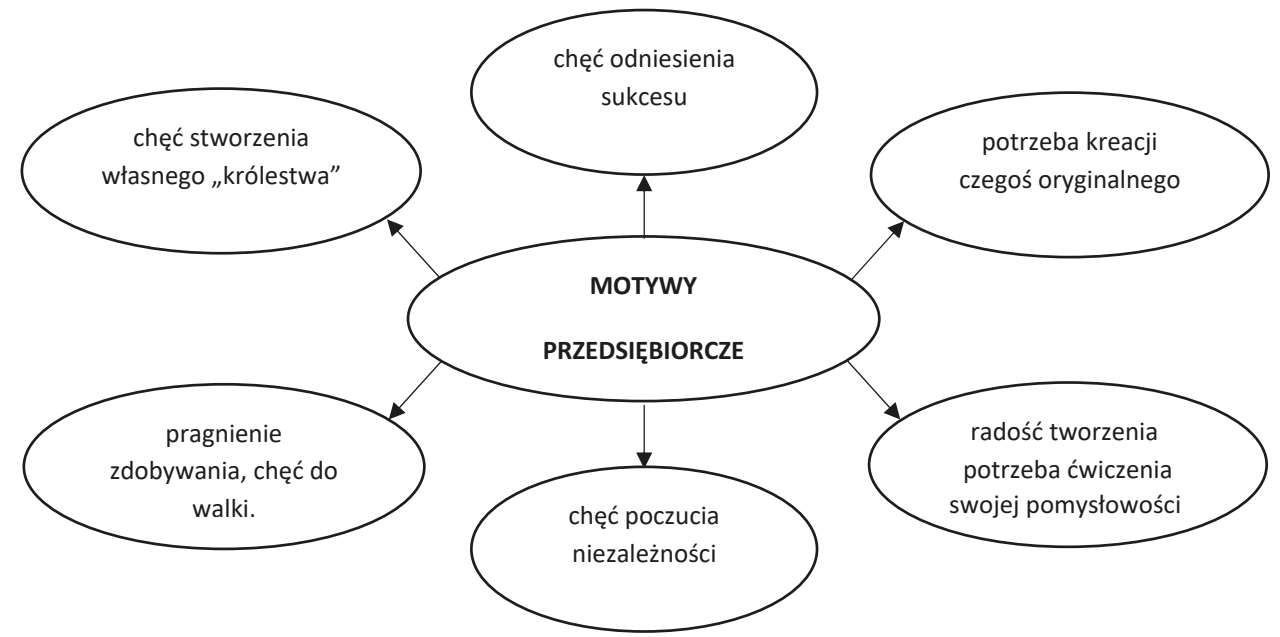

Źródło: opracowanie własne na podstawie Glapiński A., Schumpeterowska teoria przedsiębiorcy... op. cit., s. 10.

\section{Wkład w teorię przedsiębiorcy}

Poruszając temat teorii przedsiębiorczości, warto też wspomnieć o postawie przedsiębiorcy zaprezentowanej przez brytyjskiego ekonomistę Alfreda Marshalla (1842-1924), który definiuje przedsiębiorcę jako przykład racjonalnych zachowań rynkowych. Marshall nie do końca jest konsekwentny w swoich twierdzeniach, ponieważ z jednej strony uznał, że przedsiębiorcą jest właściciel środków produkcji, a z drugiej, że przedsiębiorca to kierownik zarządzający przedsiębiorstwem, albo ponoszący ryzyko inwestor kapitału. Zdaniem Marshalla przedsiębiorca jest osobą „twardo stąpającą po ziemi”, o stanowczym charakterze, dążącą do maksymalizacji zysku (w przypadku małych przedsiębiorstw do otrzymania wynagrodzenia za wykonaną pracę) oraz do poszerzenia obszaru wykonywanej działalności (w celu zwiększenia mocy produkcyjnej przedsiębiorstwa). Zatem marshallowski przedsiębiorca to posiadacz kapitału, zaangażowany w podejmowane przedsięwzięcie, lub z drugiej strony osoba gotowa do podjęcia ryzyka w cudzym imieniu, nieposiadająca własnego kapitału ${ }^{14}$.

Duży wkład w rozwój teorii przedsiębiorcy miał amerykański specjalista ds. motywacji i przedsiębiorczości David Clarence McClelland (1917-1988), który pracował nad znalezieniem cech odróżniających przedsiębiorców od innych profesji. McClelland przedstawił przedsiębiorcę jako osobę nastawioną na osiągnięcie

\footnotetext{
${ }^{14}$ I. Czaja, Przedsiębiorca $w$ teorii Alfreda Marshalla, „Zeszyty Naukowe Uniwersytetu Ekono-
} micznego w Krakowie" 2009, nr 799, s. 10-12. 
sukcesu. Sukcesem dla przedsiębiorcy miało być uruchomienie własnej firmy oraz jej dalszy rozwój. Przedsiębiorca to osoba energiczna i aktywna w działaniu, nie bojąca się podejmować umiarkowanego ryzyka ${ }^{15}$.

Bardzo mocno akcentowane w literaturze są także poglądy ekonomisty szkoły austriackiej Israela Kirznera, który twierdził, że przedsiębiorczość to nic innego, jak postrzeganie i skuteczne wykorzystywanie szans, dostarczanych przez rynek. Przedsiębiorcę cechuje czujność, otwartość na nowe wyzwania, stawianie sobie określonych celów oraz ich realizacja przy wykorzystaniu dostępnych zasobów. Kirzner podkreśla, że czujność jest najważniejszą cechą przedsiębiorcy, ponieważ dzięki temu może on dostrzec nowe źródła dochodu, czy rynki zbytu tam, gdzie inni ich jeszcze nie zauważyli. Przedsiębiorca powinien charakteryzować się szybkością w działaniu ${ }^{16}$. Dalsze próby określania przedsiębiorczości i przedsiębiorcy od końca XX wieku skupiały się wobec wyodrębnienia kategorii przedsiębiorczości jako samodzielnej dyscypliny naukowej, w związku z czym od lat 80. XX wieku zauważalny jest rozwój badań nad przedsiębiorczością. Przedsiębiorczość staje się obecnie coraz szerzej uznawanym obszarem badań, będących pretendentem do odrębnej dziedziny naukowej, w wyniku braku jednoznacznej zgody naukowców co do zdefiniowania pojęcia przedsiębiorczości.

W naukach ekonomicznych pojęcie przedsiębiorczości rozpatrywane jest jako funkcja rynku, w naukach behawioralnych przedsiębiorczość analizuje się jako funkcje przypisywane przedsiębiorcy, czyli jednostce dysponującej określonymi cechami, a w naukach o zarządzaniu przedsiębiorczość postrzega się jako proces ${ }^{17}$. Ujęcie procesowe przedsiębiorczości oznacza kreowanie nowych przedsięwzięć. Sam proces przedsiębiorczości ma na celu przyniesienie określonych z góry korzyści, poprzez realizację następujących po sobie etapów, z uwzględnieniem możliwości wystąpienia ryzyka. Według Alberta Shapero proces ten obejmuje przejawienie inicjatywy związanej z wykorzystaniem innowacyjnego pomysłu, zespolenie zasobów niezbędnych do stworzenia przedsiębiorstwa oraz dalszą swobodę działania i kontrolę funkcjonowania danego procesu przy uwzględnieniu ryzyka. Według A. Shapero podejmowanie i prowadzenie działalności gospodarczej wymagają od przedsiębiorcy pomysłowości, odwagi oraz skłonności do ponoszenia ryzyka ${ }^{18}$.

Krzysztof Wach podkreśla, iż obecnie przedsiębiorczość powinna być rozpatrywana w czterech wymiarach. Pierwszym z nich jest przedsiębiorczość jako funkcja osobowości, skupiona wobec cech ludzkiego działania, odnosząca się do przedsiębiorcy lub zespołu pracowników. Drugi wymiar według Wacha stanowi przedsiębiorczość jako funkcja czynności menedżerskich, a dokładniej badanie i rozpoznawanie zachowań menedżerskich. Kolejnym wymiarem zdefiniowanym

${ }^{15}$ D. Danilewicz, Wewnętrzne i zewnętrzne determinanty..., s. 63.

${ }^{16}$ I. Kirzner, Konkurencja i przedsiębiorczość, Fijorr Publishing, Warszawa 2010, s. 37-40.

17 A. Głodowska, Międzynarodowe porównania przedsiębiorczości krajowej w Unii Europejskiej, Wydawnictwo Naukowe PWN, Warszawa 2019, s. 19.

${ }_{18}$ M. Klonowska-Matynia, J. Palinkiewicz, Przedsiębiorczość w teorii ekonomicznej, „Zeszyty Naukowe Wydziału Nauk Ekonomicznych Politechniki Koszalińskiej” 2013, nr 17, s. 31. 
przez tego autora jest przedsiębiorczość jako funkcja indywidualnego przedsiębiorcy. Czwarty wymiar stanowi natomiast przedsiębiorczość jako funkcja rynku, czyli analiza przedsiębiorczości pod kątem jej efektów ${ }^{19}$. W wyniku rozpoznania części wspólnych definicji przedsiębiorczości dla nauk ekonomicznych, behawioralnych i nauk o zarządzaniu należy podkreślić, że we wszystkich tych dziedzinach przedsiębiorczość oznacza poszukiwanie, dostrzeganie, tworzenie oraz skuteczne wykorzystywanie okazji i możliwości w celu kreowania nowych wartości, takich jak: produkty bądź usługi, rynki zbytu, środki produkcji, formy organizacyjne, strategie itd. ${ }^{20}$

Tabela 1 .

Koncepcje przedsiębiorcy w literaturze ekonomicznej

\begin{tabular}{l|c}
\hline \multicolumn{1}{c|}{ Autor } & Definicja przedsiębiorcy \\
\hline Cantillon R., Knight F. & Przedsiębiorca to osoba ponosząca ryzyko działalności \\
\hline Schumpeter J., Drucker P.F. & Przedsiębiorca w funkcji innowatora \\
\hline \multirow{2}{*}{ Say J.B., Marshall A. } & Przedsiębiorca jest liderem przemysłu \\
\hline \multirow{2}{*}{ Say J.B., Schumpeter J. } & Przedsiębiorca w funkcji menedżera/nadzorcy \\
\cline { 2 - 2 } Cantillon R., Kirzner I. & Przedsiębiorca w funkcji organizatora i koordynatora zasobów \\
\cline { 2 - 2 } McClelland D. & $\begin{array}{c}\text { Przedsiębiorca doknuje właścicielem przedsiębiorstwa } \\
\text { stępnych zasobów }\end{array}$ \\
\hline Drucker P.F. & Przedsiębiorca to umiarkowany ryzykant, nastawiony na sukces do- \\
\hline
\end{tabular}

Źródło: K. Lewczuk, Niestabilność warunków gospodarowania a zachowania przedsiębiorstw rodzinnych, [w:] Oblicza przedsiębiorczości..., s. 35.

Dokonując analizy jedynie wybranych koncepcji przedsiębiorczości, można zauważyć, że pojęcie to stale się rozwija. Pierwsze podejścia bardziej skupiały się wokół ogólnego pojęcia przedsiębiorstwa, dostępnych zasobów, oszczędności, dokonywania inwestycji oraz mnożenia zysku. Obecnie coraz większą uwagę w naukach ekonomicznych przywiązuje się do zachowań, cech charakteru i postaw przedsiębiorców $w^{21}$. W literaturze człowiek przedsiębiorczy jest definiowany jako osoba: lubiąca przygody i działania w warunkach niepewności, podejmująca się nowych, nierutynowych działań, myśląca i działająca niezależnie, charakteryzująca się dużym optymizmem, odważna, przywiązująca ogromną wagę do swojego rozwoju, pewna siebie i świadoma zarówno swoich mocnych, jak i słabych stron, ambitna, odpowiedzialna, kreatywna, przekonywująca oraz wykazująca

\footnotetext{
${ }^{19}$ K. Wach, Przedsiębiorczość jako czynnik rozwoju społeczno-gospodarczego: przegląd literatury, „Przedsiębiorczość-Edukacja” 2015, vol. 11, s. 26-28.

${ }^{20}$ A. Głodowska, Międzynarodowe porównania przedsiębiorczości..., s. 20.

${ }^{21}$ A. Andrzejczyk, Wpływ edukacji na rozwój przedsiębiorczości, Polskie Towarzystwo Ekonomiczne, Białystok 2016, s. 12-13.
} 
się inicjatywą do działania ${ }^{22}$. Należy zaznaczyć, że przedsiębiorczość jest bardzo ważna dla rozwoju gospodarczego. Rola przedsiębiorczości w kształtowaniu gospodarki jest o tyle ważna, że przedsiębiorczość jest obecnie ważnym, szczególnie w ekonomii, działem badawczym. W dzisiejszych czasach rządy z całego świata wprowadzają w ramach swojej polityki różne działania prowadzące do rozwoju rodzimej przedsiębiorczości. Zachęcają do zakładania i prowadzenia działalności gospodarczej m.in. poprzez dotacje, stosowanie korzystniejszych systemów podatkowych czy upraszczanie przepisów na potrzeby przedsiębiorców²3.

\section{Podsumowanie}

Analizując literaturę przedmiotu z zakresu przedsiębiorczości, można stwierdzić, że przedsiębiorczość pojmowana jest dwojako. Zjednej strony rozumiana jest jako wynik ludzkiego działania, z drugiej strony jako złożony proces menedżerski. Natomiast sam przedsiębiorca, to osoba charakteryzująca się specyficznymi cechami i predyspozycjami, pomimo że koncepcje wizji przedsiębiorcy zmieniały się na przestrzeni lat, bowiem różni ekonomiści przypisywali przedsiębiorcy różne cechy.

Przytoczone koncepcje jednoznacznie wskazują, że w zasadzie niemożliwa jest pełna analiza problemu przedsiębiorczości. Możliwy jest jedynie przegląd krajowej i zagranicznej literatury tematu, a niniejsza praca powstała na bazie kilku selektywnie dobranych książek i artykułów. Na podstawie wybranej literatury przedmiotu dokonano próby usystematyzowania i utrwalenia wiedzy na temat przedsiębiorczości.

\section{Literatura}

Andrzejczyk A., Wpływ edukacji na rozwój przedsiębiorczości, Polskie Towarzystwo Ekonomiczne, Białystok 2016.

Belniak M., Internacjonalizacja jako kierunek rozwoju przedsiębiorczości firm w województwie małopolskim - wyniki badan empirycznych, [w:] J. Majczyk, M. Darecki, A. Postuła (red.), Przedsiębiorczość: jednostka, organizacja, kontekst, Wydawnictwo Naukowe Wydziału Zarządzania Uniwersytetu Warszawskiego, Warszawa 2015.

Brown Ch., Thornton M., Jak teoria przedsiębiorczości stworzyta ekonomię, „The Quarterly Journal of Austrian Economics" 2013, vol. 6, no. 4.

Czaja I., Przedsiębiorca w teorii Alfreda Marshalla, „Zeszyty Naukowe Uniwersytetu Ekonomicznego w Krakowie" 2009, nr 799.

Danilewicz D., Wewnętrzne i zewnętrzne determinanty ksztattujące postawę przedsiębiorcza [w:] Oblicza Przedsiębiorczości, B. Glinka, J. Pasieczny, A. Postuła red., Wydawnictwo Naukowe Wydziału Zarządzania Uniwersytetu Warszawskiego, Warszawa 2014.

${ }^{22}$ D. Danilewicz, Wewnętrzne i zewnętrzne determinanty..., s. 64.

${ }^{23}$ A. Andrzejczyk, Wptyw edukacji..., s. 12-13. 
Glapiński A., Schumpeterowska teoria przedsiębiorcy, czyli skąd się bierze pies, „Konsumpcja i rozwój” 2012, nr 1(2).

Głodowska A., Międzynarodowe porównania przedsiębiorczości krajowej $w$ Unii Europejskiej, Wydawnictwo Naukowe PWN, Warszawa 2019.

Huefner J.C., Hunt H.K, Robinson P.B., Stimpson D.V., An Attitude Approach to the Prediction of Entrepreneurship, „Entrepreneurship: Theory \& Practice” 1991.

Huerta de Soto J., Czterysta lat efektywności dynamicznej, Fundacja Instytut Ludwiga von Misesa, Wrocław 2010.

Kirzner I., Konkurencja i przedsiębiorczość, Fijorr Publishing, Warszawa, 2010.

Klonowska - Matynia M., Palinkiewicz J., Przedsiębiorczość w teorii ekonomicznej, „Zeszyty Naukowe Wydziału Nauk Ekonomicznych Politechniki Koszalińskiej” 2013, nr 17.

Koolman G., Say's Conception of the Role of the Entrepreneur, „Economica New Series” 1971, vol. 38, no. 151.

Korol J., Kusideł E., Szczuciński P., Przedsiębiorczość, produktywność i konkurencyjność regionów Polski, Wydawnictwo Adam Marszałek, Torun 2016.

Lewczuk K., Niestabilność warunków gospodarowania a zachowania przedsiębiorstw rodzinnych, [w:] Oblicza Przedsiębiorczości, B. Glinka, J. Pasieczny, A. Postuła (red.), Wydawnictwo Naukowe Wydziału Zarządzania Uniwersytetu Warszawskiego, Warszawa 2014.

Macko A., Tyszka T., Przedsiębiorczość i ryzykowanie, „Decyzje” 2005, nr 4.

Mises L. von, Ludzkie działanie, Traktat o ekonomii, Instytut Ludwiga von Misesa, Warszawa 2007.

Pelizza Vier Machado H., Jorge Nassif V.M., Documentos e Debates: Réplica - Empreendedores, Réplica - Empreendedores: Reflexões sobre Concepções Históricas e Contemporâneas, „RAC, Rio de Janeiro” 2014, vol. 18, no. 6.

Schumpeter J.A., Kapitalizm, socjalizm, demokracja, PWN, Warszawa 1995.

Wach K., Przedsiębiorczość jako czynnik rozwoju społeczno-gospodarczego: przegląd literatury, „Przedsiębiorczość-Edukacja” 2015, vol. 11. 